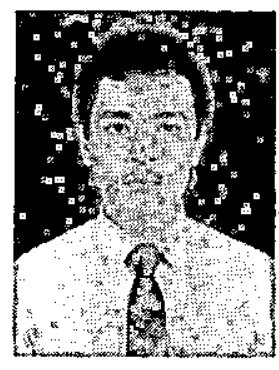

\title{
PENGAKUAN DAN \\ PELAKSANAAN PUTUSAN \\ ARBITRASE ASING DI \\ INDONESIA : \\ ANALIS PERMASALAHAN
}

\section{O1eh. Nandang Sutrisio}

Perdagangan lintas negara saat ini demikian komplek. Itu berarti persinggungan konflik dan sengketa karenanya semakin terbuka pula. Dalam kaitan ini putusan arbitrase asing.semakin memegang peranan penting. Namun dukungan pengadilan merupakan elemen kunci dari sukses atau gagalnya pengakuan dan pelaksanaan putusan arbitrase asing.

$\mathrm{P}$ engakuan dan pelaksanaan (recognition and ofercement) putusan arbitrase asing merupakan suatu tahapan yang sangat jika bukan paling penting dan krusial dari keseluruhan proses arbitrase (perdagangan) internasinal. Hal ini tidak lain karena tahapan ini merupakan parameter dari sukses atau gagalnya sebuah arbitrase. Arbitrase perdagangan internasional tidak dapat dikata- kan berhasil jika produk putusannya tidak dapat diakui dan dilaksanakan.

Bagi kebanyakan negara, khususnya negara-negara berkembang, tahapan ini merupakan tahapan yang paling sulit dan problematik. Di negara-negara ini putusan arbitrase asing umumnya dapat diakui dan dilaksanakan. Indonesia merupakan salah satu negara, diantara negara-negara berkembang tersebut, yang masih belum dapat mengakui dan melaksanakan putusan arbitrase perdagangan internasinal sebagaimana mestinya. Paling tidak, ada tiga hal yang mendasar yang laik dicurigai sebagai kendala: pertama, kurang memadainya perangkat yuridis dalam bidang arbitrase, khususnya arbitrase perdagangan internasional; kedua, inkonsistensi masyarakat bisnis (pengusaha-pengusaha) indonesia terhadap kontrak-kontrak bisnis yang mereka buat dengan masyarakat bisnis asing; ketiga, sikap pengadilan Indonesia yang kurang "ramah" terhadap putusan arbitrase asing. 
Meningkatnya intensitas interaksi bisnis internasinal yang tidak mau melibatkan masyarakat bisnis Indonesia, memaksa negara-negara ini untuk dapat segera mengantisipasi masalah-masalah tersebut, kerena dalam percaturan bisnis Internasional, arbitrase merupakan suatu instrumen hukum yang penting dan lebih disukai masyarakat bisnis, ketimbang pengadilan, dalam menyelesaikan sengketa (dispute) bisnis. OLeh karena itu, hendaknya hal ini merupakan salah satu agenda besar yang perlu mendapat porsi perhatian yang serius dalam PJPT II bidang hukum. Dapat diantisipasinya masalah ini akan merupakan kontribusi besar terhadap perbaikan citra hukum Indonesia di mata Internasional, yang selama ini berkesan "there is no law in Indonesia".

Tulisan ini akan mencoba menganalisis permasalahan yang terkait dengan pengakuan dan pelaksanaan putusan arbitrase asing di Indonesia dengan memfokuskan pada tiga variabel kendala sebagaimana disebutkan di muka, dengan maksud untuk memetakan permasalahan tersebut dalam kerangka pencarian solusi strategis yang dapat direkomendasikan.

\section{Deskripsi Permasalahan.}

Alasan mendasar belum dapat diakui dan dilaksanakan putusan arbitrase perdagangan asing di Indonesia bervariabel menurut kurun waktu tertentu. Sebelum tahun 1981, putusan arbitrase asing belum dapat diakui dan dilaksanakan berdasarkan suatu alasan bahwa Indonesia belum meratifikasi Konvensi New York. ${ }^{1)}$ dari tahun 1981 sampai tahun 1990, kendala baru muncul; meskipun pada tahun 1981, dengan Kepres No. 34 tahun 1981 Indonesia meratifikasi Konvensi New York, putusan arbitrase asing masih belum dapat dilaksanakan, karena Mahkamah Agung berdapat bahwa Konvensi tersebut masih memerlukan peraturan pelaksanaan. Pada tahun 1990, peraturan pelaksanaan yang dinanti-nantikan tersebut akhimya dikeluarkan, yakni peraturan Mahkamah Agung Republik Indonesia No. 1 Tahun 1990 (PERMA). Namun dengan dikeluarkannya peraturan tersebut tidak serta merta menjamin dilaksanakannya putusan arbitrase asing, yakni putusan the Queen's Counsel of the English Bar dalam kasus E.D. \& F. MAN (Sugar) Limited v. Yani Haryanto, 2 ) putusan tersebut masih belum dapat dieksekusi, karena tergugat mengajukan kasasi.

\section{Perangkat Yuridis Arbitrase}

Perdagangan Internasional di

\section{Indonesia.}

Dari deskripsi singkat masalah tersebut di muka, ada beberapa persoalan hukum yang mendasar yang muncul. Pertama, apakah tidak diratifikaasinya Konvensi New York merupakan alasan yang kuat bagi Indonesia untuk tidak melaksanakan putusan arbitrase asing?

Persoalan ini laik dimunculkan mengingat adanya suatu fakta bahwa sebelum Indonesia merdeka, yakni pada tahun 1931, pemerintah Belanda telah meratifikasi Konvensi Genewa 1927 dan memperluas penerapannya kepada Hindia Belanda (Indonesia). Kedua, apakah Konvensi New York dan Kepres No. 34 Tahun 1981 memerlukan peraturan pelaksanaan? Ketiga, apakah tidak ada dasar hukum lain, selain kovensi internasinal, yang dapat digunakan sebagai landasan hukum dalam melaksanakan putusan arbitrase asing?

1) The New York Convention of 1958 of Recognition and Enforcement of Foreign Arbitral Awards (Konvensi New York 1958 mengenai Pengakuan dan Pelaksanaan Putusan Arbitrase Asing) (selanjutnya Konvensi New York), 10 Juni 1958.

2) E.D. \& F. MAN (Sugar) Limited v. Yani Haryanto, Putusan Mahkamah Agung Republik Indonesia No. 1 Pen. Ex'r/Arb. Int./Pdt/1991, 1 Maret 1991. 
Dalam konteks permasalahan pertama, Mahkamah Agung berpendapat bahwa meskipun pemerintahan Belanda meratifikasi Konvensi Genewa 1927 serta memperluas daya berlakunya kepada Indonesia, dan meskipun pasal 5 konferensi Meja Bundar menyatakan bahwa Indonesia akan terikat oleh perjanjian-perjanjian intemasional yang ditandatangani oleh pemerintah Belanda untuk Indonesia, kecuali kalau Indonesia menyatakan secara tegas keluar dari perjanjian-perjanjian tersebut, sesuai dengan prinsip-prinsip baru hukum intemasional yang terkait dengan "state succession," yang berlaku setelah Perang Dunia II, Indonesia tidak lagi terikat oleh perjanjian-perjanjian internasinal yang diakses selama masa kolonial. ${ }^{3)}$

Pendapat ini diperkuat oleh pendapat Prof. Z. Asikin Kusumah Atmadja t) yang menyatkan bahwa sejak Konvensi Meja Bundar, Konvensi Genewa 1927 sudah tidak berlaku lagi. Fakta historis bahwa pemerintah Belanda masih mengusai Irian Jaya sampai 1963 dan tidak ditepatinya Konferensi Meja Bundar oleh pemerintah Belanda, merupakan dasar yang kuat bagi Indonesia untuk secara unilateral menghentikan kewajiban-kewajiban yang timbul dari konferensi tersebut, sesuai dengan rebus sic stantibus dalam UU No. 1 Tahun $1965^{5)}$. Dalam suatu diskusi dengan Prof. Sudargo Gautama, Prof. Asikin juga berpendapat bahwa dalam hal suksesi, Indonesia menganut sistem aktif. ${ }^{6}$

Kenyataannya, Indonesia tidak pernah menyatakan secara aktif dan tegas masih akan tetap terikat oleh Konvensi Genewa. Berbeda dengan Prof. Asikin, Prof. Gautama berpendapat bahwa Indonesia menenut sistem pasif. ${ }^{7)}$ Sejauh mengenai Konvensi Genewa 1927, Indonesia tidak pernah menyatakan secara tegas menarik diri dari konvensi tersebut. Oleh karena itu, menurutnya, konvensi tersebut masih tetap berlaku. Robert N. Homick juga berpendapat serupa. Setelah mereka, menurutnya, Indonesia masih tetap sebagai anggota Konvensi Genewa 1927, dan oleh karena itu putusan arbitrase asing seharusnya dapat dilaksnakan sesuai dengan konvensi tersebut. 8)

Tidak satu pun pendapat di muka mendasarkan diri pada Undang-undang Dasar 1945, padahal Pasal II Aturan Peralihan secara jelas menyuratkan bahwa hukumhukum atau peraturan-peraturan yang berlaku pada masa pemerintahan kolonial yang masih tetap berlaku sepanjang tidak bertentangan dengan Undang-undang Dasar tersebut, dan tidak ada hukum-hukum atau peraturanperaturan baru mencabut atau menggantikannya. Ini berarti bahwa secara yuridis konstitusional Konvensi Genewa 1927 masih tetap berlaku. Dengan demikian alasan masih tidak dapat dilakikannya putusan arbitrase

3) Putusan Mahkamah Agung Ri No. 294 K.Pdt/1983, 20 Agustus 1984.

4) Lihat W.E. Kusnandar, "Perkembangan dan Hambatan Pelaksanaan Arbitrase Asing di Indonesia," Newsaletter, Vol. 7/1 1 Tahun 1991, hal. 1.

5) Ibid., hal. 2.

6) S. Gautama. "Some Legal Aspect of International Commercial Arbitration in Indonesia," J. Int'I Arb., Vol. 7 Tahun 1990, hal. 102. Menurut sistem aktif, Indonesia dianggap sebagai anggota dari konvensi-konvensi internasional yang dibuat sebelum kemerdekaan jika hal itu dinyatakan secara tegas.

7) Ibid. Menunut sistem pasif, konvensi-konvensi internasional yang diakses pada masa pra-kemerdekaan masih tetap berlaku, kecuali jika Indonesia secara tegas membatalkan keanggotaannya dan menyatakan bahwa ia tidak akan terikat lagi oleh konvensi-konvensi tersebut. Ini berarti bahwa jika Indonesia ingin keluar dari konvensi-konvensi tersebut, Indonesia harus menyatakan secara tegas. Sebagai contoh, disamping menyatakan menarik diri dari Konvensi Meja Bundar, Indonesia juga pernah menyatakan keluar dari Bern Copyright Convention.

8) R.N. Hornick. "The Recognition and Enforcement of Foreign Judgments in Indonesia," Harv. Int'l L.J., Vol. 18 Tahun 1977, hal .102. 
asing karena belum diratifikasinya Konvensi New York tidaklah sepenuhnya tepat.

Permasalahan kedua laik kemukakan sebagai respon terhadap sikap Mahkamah Agung dalam kasus Navigation Maritine Bulgare (NMB) v. PT Niswar. ${ }^{9)}$ Dalam kasus ini, NMB, sebuah perusahaan perkapalan Bulgaria, mengajukan permohonan exequatur kepada Mahkamah Agung Republik Indonesia atas suatu putusan arbitrase yang dibuat di Inggris. Putusan arbitrase tersebut memerintahkan PT. Niswar untuk membayar klaim sebesar US\$ 72.576,39 ditambah bungan 7,5 persen pertahu, terhitung mulai 1 Januari 1975 sampai dilaksanakannya putusan. Mahkamah Agung menolak untuk memberikan exequatur dengan dalil bahwa Kepres No. 34 Tahun 1981 yang meratifikasi Konvensi. New York tersebut masih memerlukan peraturan pelaksanaan. ${ }^{10}$ )

Prof. Sudargo Gautama tidak sependapat, sebab menerutnya, hukum Indonesia tidak mensyaratkan adanya peraturan pelaksanaan untuk melaksanakan suatu konvensi. 11) Dalam Pasal III Konvensi New York sendiri dinyatakan bahwa setiap negara anggota harus mengakui putusan arbitrase sebagai suatu putusan yang mengikat secara hukum, dan melaksanakannya menurut Prosedur lex fori serta syarat-syarat yang ditentukan dalam konvensi. Pasal ini juga menekankan agar daalam pengakuan dan pelaksanaan putusan arbitrase asing tidak dikenakan syarat-syarat yang lebih berat atau biaya yang lebih tinggi daripada pengakuan dan pelaksanaan putusan arbitrase domestik. M. Yahya Harahap, ini berarti bahwa konvensi tersebut telah menetapkan prinsip jus sanguinisP atau prinsip personality. ${ }^{12)}$ Berdasrkan hal-hal tersebut di muka, dapat dikatakan bahwa pengakuan dan pelaksanaan putusan arbitrase asing dapat dilakukan menurut prosedur eksekusi putusan arbitrase domestik.
Meskipun sampai tahun 1990, bahkan sampai saat ini, Indonesia belum memiliki undang-undang yang khusus mengatur arbitrase, terdapat beberapa landasan yuridis, yang dapat dijadikan pedoman dalam pengakuan dan pelaksanaan putusan arbitrase. Secara substantif, landasan yang paling umum ialah pasal 1338 KUHPerdata, karena bagaimana pun juga kontruksi yuridis arbitrase adalah perjanjian. Landasan yuridis ini didukung pula oleh penjelasan Pasal 3 Undang-undang No. 1 Tahun 1970, yang memberikan justifikasi terhadap eksistensi penyelesain sengketa melalui arbitrase. Secara prosedural, Pasal 377 HIR menunjuk secara langsung secara Rv. Ketentuan mengenai Arbitrase dapat ditemukan dalam Buku Ketiga, Bab Pertama, Pasal 615-651 Rv. Namun dalam konstelasi Iandasan yuridis yang terakhir ini, secara teoritis timbul masalah. Seperti diketahui bahwa Rv. telah dicabut oleh HIR pada tahun 1941. Dengan demikian ada ketidak jelasan status Rv. itu sendiri. Dalam konteks ini, Hornick berpendapat bahwa "Articles should be considered to be an exception."13) Oleh karena itu, pasal-pasal tersebut masih tetap berlaku. Dengan demikian, adanya peraturan pelaksanaan bagi Konvensi New York dan Kepres No. 34 Tahun 1981 sebenarnya secara yuridis bukanlah merupakan suatu conditio sine qua non.

Namun dilihat dari segi praktis. esksistensi PERMA sebagaimana dimaksud ada mamfaatnya, karena landasa yuridis yang

9) Navigation Maritime Bulgare (NMB) v. PT -Nizwar, Putusan Mahkamah Agung Republik Indonesia No. 2944 K/Pdt/1983, 29 Nopember 1984.

10) Ibid.

11) S. Gautama, Supra no. 6.

12) M.Y. Harahap, Arbitrase, Pustaka Kartini, Jakarta, 1991, hal. 62.

13) R.N. Hornick, "Indonesian Arbitration in Theory and Practice," Am. J. Comp. L., Vol. 39, Tahun 1991, hal. 575. 
ada akan minimbulkan kesulitan manakala diterapkan terhadap prosedur pengakuan dan pelaksanaan putusan arbitrase asing tidak dideponer pada pada pangadilan negeri Indonesia mana pun, kesulitan yang akan timbul ialah pengadilan negeri manakah yang mempunyai kompetensi mengeluarkan exequator. Dengan adanya peraturan pelaksanaan, masalah tersebut telah dapat diantisipasi.

\section{Inkonsistensi Masyrakat Busnis}

\section{Indonesia}

Selain disebabkan adanya problema yuridis sebagaimana diuraikan dimuka, terhambatnya pengakuan dan pelaksanaan putusan arbitrase asing merupakan konsekkuensi logis dari inkonsistensi masyarakat bisnis Indonesia terhadap klausula-klausula arbitrase yang mereka buat dalam kontrak-kontrak bisnis Internasional. Mereka kurang menghormati, dan oleh karena itu mereka tidak melaksanakan secara suka rela, bahkan melakukan bantahan atau perlawanan.

Adalah sangat sukar untuk mengetahui latar belakang sikap mereka, karena belum ada studi yang intensif mengenai hal tersebut. Terlebih lagi apabila dikaitkan dengan fakta bahwa pada masa prakemerdekaan, arbitrase perdagangan intemasional merupakan praktek yang umum di Indonesia, dan para pihak yang terlibat melaksanakan putusan arbitrase asing secara suka rela. Selain itu, sampai saat ini, para pengusaha Insdonesia pada umumnya melaksanakan putusan arbitrase domestik secara suka rela. Berikut ini suatu latar belakang historis dan beberapa spekulasi teoritis yang mungkin berguna dalam memahami fenomena tersebut.

Selama masa penjajahan Belanda, Indonesia mempunyai struktur perekonomian. yang didominasi oleh perusabaan-perusahaan asing, termasuk perusahaan-penusahaan
Cina. ${ }^{14)}$ Hampir keseluruhan perusahaan besar, seperti perusahaan-perusahaan perkebunan, pertambangan, perdagangan internasional, industri dan perbankan merupakan perusahaan-penusahaan milik Belanda. Sedangkan para pengusaha (pedangan) Cina ditempatkan sebagai perantara perusahan-perusahaan Belanda dan perusahaan-perusahaan asing lainnya dengan pribumi. Dalam "struktur kasta kolonial," yang bersifat rasial dan didasarkan pada sistem stratifikasi sosial, para pedagang Cina tersebut menempati status yang penting sebagai kelas menengah. Sedangkan pribumi Indonesia diberi posisi yang paling rendah.

Akibat dari adanya stratifikasi tersebut, dapat dipahami apabila bisnis-bisnis modern, khususnya transaksi-transaksi perdagangan internasional, merupakan transaksi-transaksi antara perusahaan-perusahaan Belanda, dan perusahaan-perusahaan asing lain yang berlokasi di negara masing-masing. Sedangkan pribumi tidak diberi kesempatan untuk berkiprah dalam transaksi-transaksi perdagangan internasional tersebut; mereka hanya terlibat dalam pertanian subsitusi dan bisnis kecil (small business). Tidak heran apabila arbitrase pun hanya merupakan budaya penyelesaian sengketa diantara perubahan-perubahan Belanda dan non-Indonesia lainnya; tidak melaksanakan putusan arbitrase akan berarti terganggunya kelancaran bisnis mereka. Oleh karena itu arbitrase perdagangan internasional banyak dipraktekkan, dan putusan- putusan dari arbitrase tersebut dilaksanakan suka rela, tanpa mengalami hambatan yang berarti. ${ }^{15)}$

Pad masa awal kemerdekaan Indonesia, praktek-praktek arbitrase perdaagangan

14) Yahya A. Muhaimin, Bisnis dan Politik: Kebijaksanaan Ekonomi Indonesia 1950-1980, LP3ES, Jakarta, 1991, hal. 2.

15) Gautama, Supra No. 6, hal. 96. 
internasional mengalami penurunan yang signifikan. ${ }^{16)}$ Secara historis, menurunnya arbitrase perdagangan inemasional merupakan konsekuensi logis dari bencana perekonomian yang disebabkan oleh penjajahan Jepang. Penjajahan Jepang telah menghancurkan perekonomian Indonesia; impor pada umumnya dilarang, peralatan industri dikirim ke luar negari, suplay pekerja secara drastis dkurangi, dan aset-aset dikuasainya. ${ }^{17}$ ) Paada tahun 1945 (setelah Indonesia merdeka), Jepang mengembalikan aset-aset asing tersebut. Namum meskipun demikian aktivitas-aktivitas bisnis tetap lemah; praktis tidak ada investasi-investasi baru.

Kurang dari setahun setelah pemerintah Belanda mengakui kedaulatan Indonesia, pemerintah Indonesia menerapkan "Rencana Urgensi Perekonomian" yang sangat bersifat nasionalistik, sebagai upaya untuk merubah struktur perekonomian kolonial. ${ }^{18)}$ Dalam kerangka ini pemerintah menjalankan kebijakan ekonomi yang ambisius yang diberi nama "Program Banteng", yang bertujuan untuk melindungi dan mengembangkan pengusaha-pengusaha asing dan Cina, serta mengurangi ketergantungan terhadap mereka. ${ }^{19)}$ Pemerintah, disamping menasionalisasi perusahaan-perusahaan Belanda, Inggris dan Malaysia, juga memberikan lisensi-lisensi impor dan memerikan fasilitas-fasilitas kredit hanya pada pengusaha-pengusaha domestik.

Tujuan utama kebijakan seperti itu adalah untuk mengakumulasi kapital melalui transaksi-transaksi impor yang akan mendorong pembangunan industri. Namun kebijakan swperti ini telah dijadikan suatu alat transaksi fasilitas antara para birokrat, yang didominasi oleh anggota-anggota partai yang berkuasa, dengan para pendukungnya yang menjadi klien-klien ekonomi mereka. Sejak saat itulah tumbuhlah apa yang disebut "client.businessmen," ${ }^{20)}$ yang didukung oleh kebijakan-kebijakan proteksi pada setiap periode. Pertumbuhan jenis pengusaha seperti itu diakselerasi oleh Undang-undang Penanam Modal Asing pada tahun 1967 dan Undang-undang Penanaman Modal Dalam Negeri tahun 1968, yang memberikan otoritas penuh kepada pemerintah atau birokraat untuk mengalokasikan kapital, kredit, konsensi dan lisensi kepada klien tersebut. Oleh karena itu, kolusi birokrat-pengusaha yang bersifat "simbiose mutualistis" telah menjadi budaya yang tidak dapat dihindarkan. Dari latar belakang historis tersebut, tampak adanya suatu kaitan erat antara tumbuh suburnya "client businessmen" dengan keenggangan para pengusaha Indonesia untuk melaksanakan putusan arbitrase asing. Budaya paternalistik yang ditimbulkan oleh "client businessmen" dapat ditunjuk sebagai causa prima. Sedemikian intensnya pola ini, sehingga "genuine businessmen" pun pada umumnya terjebak ke dalamnya. Dengan melakukan penolakan untuk melaksanakan putusan arbitrase asing, pengusaha Indonesia mengharapkan agar pihak asing membawa ke pengadilan Indonesia. Pengusaha Indonesia yakin bahwa pengadilan, selaku institusi pemerintah, akan melindungi dan berpihak kepada mereka.

16) Ibid.

17) H. Hill, Investasi Asing dan Industrialisasi di Indonesia, LP3ES, Jakarta, 1991, hal. 13.

18) Muhaimin, supra no. 14, hal.5.

19) Ibid.

20) Muhaimin, supra no. 18. Lihat juga $C$. Wibisono, "Anatomi Konglomerat Indonesia," dalam K.K. Gie \& B.N. Marbun, Konglomerat Indonesia: Permasalahan dan Sepak Terjangnya, Pustaka Sinar Harapan, Jakarta, 1990, hal. 15. Wibisono menggunakan istilah ersatz capitalist, yang juga digunakan oleh Kunio Yoshihara, untuk produktivitas, kreativitas, kerja keras disiplin, motivasi dan dedikasinya, tetapi lebih dikarenakan oleh pemberian lisensi-lisensi birokrat, akses terhadap penguasa, atau statusnya sebagai suatu agen Perusahaan Multi Nasioanal. 
Dengan demikian, hal ini tampaknya akan menolak anggapan bahwa sikap membangkannya penguasa Indonesia terhadap putusan arbitrase asing disebabkan oleh kurangnya kesadaran hukum dan kurangnya pengetahuan mereka akan arbitrase. Hal ini didukung oleh fakta tidak adanya permohonan exequator untuk putusan arbitrase yang dikeluarkan oleh Badan Arbitrase Nasional Indonesia (BANI) sejak 1977, telah dilaksanakan secara suka rela. ${ }^{21)}$

Selain alasan historis sebagaimana dipaparkan di muka, dapat pula diasumsikan bahwa "sikap membangkang" pengusahapengusaha Indonesia terhadap putusan arbitrase asing dilakukan sebagai suatu dilatory tactic (taktik mengulur-ulur waktu) sebagaimana yang terjadi dalam praktek pelaksanaan putusan penagdilan. Dengan melakukan taktik ini, pihak yang kalah akan mengambil langkah-langkah yang dianggap perlu untuk menyelamatkan aset-asetnya. Ia mungkin mentransfer aset-asetnya kepada familinya atau kepada pihak ketiga lainnya, atau menyatakan pailit, sehingga pihak pemenang mungkin tidak mendapatkan apa pun, dan ia hanya menang di atas kertas.

Alasan lain yang dapat dikemukakan adalah bahwa pengusaha-pengusaha Indonesia, sebagai pihak yang kalah, memamfaatkan celah-celah hukum dalam sistem hukum Indonesia, khususnya yang menyangkut arbitrase perdagangan internasional. Meraka berspekulasi, berdasarkan kelemahan hukum tersebut, bahwa permohonan exequatur oleh pihak asing akan ditolak. Kasus-kasus Navigation Maritime Bulgare (NMB) v. PT. Niswar dan E. D. \& F. MAN (Sugar) Limited v. Yani Haryanto merupakan ilustrasi yang membuktikan kebenaran spekulasi tersebut.

Akhirnya, secara substantif hukum sendiri memberikan kemungkinan bagi pihak-pihak yang terlibat untuk menolak pelaksanaan putusan arbutrase asing. ${ }^{22)}$ Kasus Trading Corporation of Pakistan Limited (TCPL) v. PT. Bakrie Brothers dapat dikatakan sanagt ilustratif.

Realitas bahwa pengusaha-pengusaha Indonesia tidak mematuhi putusan arbitrase asing, apabila dikaji lebih jauh, tampak agak janggal dan parodox. Sebab dilihat dari prespektif dependensi pengusaha-pengusaha Indonesia terhadap pengusaha-pengusaha asing, terutama dalam hal kapital, agaknya sangat kecil kemungkinannya bahwa meraka mengabaikan putusan arbitrase asing dengan berdalih bahwa putusan tersebut tidak dapat dilaksanakan. Setiap pengusaha Indonesia yang terlibat dalam bisnis Internasional mestinya sudah mempertimbangkan ekses yang akan timbul terhadap reputasi bisnisnya, apabila ia menolak melaksanakan putusan arbitrase asing meskipun secara teknis yuridis putusan tersebut mungkin tidak dapat dilaksanakan. Tetapi, pertimbangan tersebut tampaknya absen, dan "sikap membangkang" mereka dapat dipandang sebagai kompensasi dari ketidakseimbangan posisi mereka dalam kontrak bisnis internasional.

Sikap Pengadilan Indonesia: nonenforcement policy?

Secara umum, pengadilan Indonesia kurang memberikan dukungan terhadap pelaksanaan putusan arbitrase perdagangan intemasional di Indonesia. Tidaklah berlebihan apabila dikatakan bahwa

21) Hornick, supra no. 13, hal. 573.

22) Baik Konvensi New York maupun PERMA memberikan dasar-dasar untuk menolak pelaksanaan putusan arbitrase asing.

23) Trading Corporation of Pakistan Limited (TCPL) v. PT Bakrie Brothers, Putusan Pengadilan Negri Jakarta Selatan No. 64/Pd/G/1984. Dalam kasus ini pengadilan menjastifikasi dalil penolakan Termohon, PT Bakrie Brothers, yang melandaskan pada Pasal I(3) dan Pasal V Konvensi New York.

24) S. Gautama, Aneka Masalah Hukum Perda- 
pengadilan Indonesia menerapkan non-enforcement policy. . Munculnya alasan banu pada setiap periode tertentu, yang didalilkan oleh pengadilan Indonesia untuk menolak pengakuan dan pelaksanaan putusan arbitrase asing, merupakan bukti kuat yang menggambarkan sikap tersebut. Kendati sangant sulit diketahui secara pasti, tiga hal penting dapat diidentifikasi sebagai latar belakang sikap pengadilan tersebut dimuka: tidak dapat dilaksanakannya putusan pengadilan asing menurut sistem hukum Indonesia, tidak dihargainya pilihan hukum dan pilihan forum Indonesia oleh negara-negara asing, dan upaya melindungi pihak Indonesia yang mempunyai posisi lemah dalam kontrak-kontrak bisnis internasional.

Sikap kurang mendukung pengadilan Indonesia terhadap putusan arbitrase asing dapat dikatakan merupakan pengaruh psikologis dari sistem hukum Indonesia sendiri yang menentukan bahwa putusan pengadilan asing tidak dapat dilaksanakan di Indonesia. ${ }^{24)}$ Hal ini dapat dilihat dari ketentuan Pasal 436 Rv. Mengikuti klasifikasi metoda pelaksanaan putusan pengadilan asing yang dibuat oleh A. Caffrey, ${ }^{25)}$ Indonesia menganut evidentiary method yang memperlakukan putusan pengadilan asing semata-mata hanya sebagai barang bukti. Sesuai dengan metoda ini, seluruh klaim, kecuali yang ditentukan dalam pasal 436(1), harus diperiksa kembali, dan dengan demikian memberikan otoritas kepada pengadilan untuk memeriksa kembali obyak perkara. Sistem seperti ini secara psikologis berpengaruh pula terhadap pelaksanaan putusan arbitrase asing, karena hakim-hakim yang menangani permohonan pelaksanaan putusan arbitrase asing ialah meraka yang juga menangani pemohonam pelaksanaan putusan pengadilan asing. Selain itu, ada semacam kerancuan bahwa dalam pasal 436 apa yang dimaksud dengan penagdilan asing didefinisikan di dalam Pasal 440 meliputi juga putusan arbirase asing.

Pengusaha-pengusaha asing yang melkukan transksi dengan pengusahapengusaha Indonesia biasanya mengusulkan untuk mencantumkan klausula-klausula pilihan hukum dan pilihan forum asing (bukan Indonesia) dalam kontrak-kontrak bisnis yang mereka buat. Kalau pun ada, pilihan hukum dan pilihan forum yang menunjukkan hukum dan pengadilan Indonesia tidak selalu dihormati di negara-negara laain. ${ }^{26)}$ Kalangan bisnis dan ahli-ahli hukum asing yang menganggap bahwa: hukum dan pengadilan Indonesia masih belum cukup mampu untuk menangani sengketa-sengketa bisnis yang bersifat multinasional. Berdasrkan hal ini, meskipun dalam suatu kasus tertentu terdapat klausula pilihan hukum dan pilihan forum Indonesia, pengadilan Inggris pernah menganggap bahwa pilihan hukum dan pilihan forum Indonesia tidak berlaku, dan mengklaim bahwa pengadilan Inggrislah yang mempunyai yurisdiksi. ${ }^{27)}$ Bahkan pengadilan Hongkong pernah menyatakan

ta Internasional, Alumni, Bandung, 1985, hal. 281; Tumbuan \& Associate, "Indonesia," dalam C. Platto ed., Enforcement of Foreign Judgment Worldwide, Graham \& Trotman and International Bar Associate, London, 1989, hal. 53.

25) B.A. Caffrey, International Jurisdiction and Recognation and Enforcement of Foreign Judgments in the LAWASIA Region: A Comparative Study of the Law of Eleven Asian Countries Inter-se and with the E.E.C. Countries, CCH Australian Limited, New South Wales, 1985, hal. 66. Caffrey metoda pelaksanaan putusan pengadilan asing kedalam lima kelompok: the English, Indian, Japanese, Evidentiary dan Appeal Methods.

26) S. Gautama, Masalah-masalah Baru Hukum Perdata Internasional, Alumni, Bandung, 1984, hal. 35.

27) Ibid., hal. 42. 
bahwa sengketa harus diperiksa di Hongkong, karena Di Indonesia tidak ada hukum. ${ }^{28}$

Tidak dihormatinya pilihan hikum dan pilihan forum Indonesia sebagaimana terungkap dimuka, merupakan dasar justifikasi bagi pengadilan Indonesia untuk secara resiprositas berbuat senupa. Hal ini berarti keenggangan mereka untuk melasanakan putusan pengadilan atau putusan arbitrase asing hendaknya difahami sebagai respon atas perlakuan negara-negara asing terhadap hukum dan pengadilan Indonesia.

Latar belakang yang tidak kalah pentingnya untuk memahami sikap pengadilan Indonesia terhadap putusan arbitrase asing ialah keinginan untuk melindungi pengusaha-pengusaha Indonesia ynag mempunyai posisi lemah dalam kontrak-kontrak bisnis internasional. Dalam konteks ini, Noles mengatakan bahwa "a refusal to enforce typically occurs the court determines that a substantial inequality in bargaining power existed at the time the contract was formed. ${ }^{29)}$ Sebagai contoh, pengadilan yang hanya menguntungkan pihak-pihak yang mempunyai bargaining power yang superrior yang dapat memaksa pihak-pihak yang lemah untuk tunduk kepada yurisdiksi suatu pengadilan asing yang sehanusnya tidak mereka pilih.

Lemahnya bargaining power ${ }^{30}$ ) pengusaha-pengusaha Indonesia, vis a vis pengusaha-pengusaha asing, sering menggiring mraka kedalam posisi ketergantungan. Akibatnya, mereka kerap begitu saja menerima klausula-klausula pilihan hukum dan pilihan forum, dalam kontrak yang biasanya adhesif, meskipun itu hanya mengutungkan pengusaha-pengusaha asing.

Arbitrase perdagangan internasional merupakan pilihan forum yang paling disukai oleh pengusaha-pengusaha asing. Dalam pandangan negara-negara berkembang, arbitrase perdagangan internasional merupakan suatu sistem yang bias yang berpihak kepada negara-negara pengekspor kapital, dan merupakan suatu instrumen subjigasi, serta merupakan suatu produk dominasi negara-negara barat. ${ }^{31)}$ Kecurigaan semacam itu timbul mengingat suatu fakta bahwa pengusaha-pengusaha negara pengekspor kapital, yang umumnya berasal dari negara-negara maju, telah bensaha membangun suatu sistem arbitrase untuk melindungi kontrak-kontrak investasi dan aktivitas-aktivitas bisnis mereka yang terkait, dalám konteks hukum internasional. Tidak mengherankan apabila pengusaha-pengusaha Indonesia senantiasa dalam posisi kalah. Keengganan pengadilan Indonesia untuk melaksanakan putusan arbitrase asing dapat dipandang sebagai suatu ekspresi dari sentisivitas mereka terhadap eksploitasi. Adalah beralasan apabila pengadilan memberikan perferensi perlakuan kepada pihak (pengusaha) Indonesia, karena tanpa periakuan khusus semacam itu aktivitas-aktivitas perusahaaan-perusahaan akan terus menerus menjadi beban.

\section{Cacatan Penutup}

Diratifikasinya Konvensi New York pada tahun 1981, dikeluarkan PERMA pada tahun 1990, dan dikabulkannya permohonan exquatur pada tahun 1991 merupakan indikasi adanya upaya yang serius untuk

28) Ibid., hal. 43.

29) C. Noles, "Enforcement of Forum Selection Agreement in Contracts Between Unequal Parties," Ga. J. Int'1 \& Comp. L., Vol. 11 Tahun 1981, hal. 693.

30) Lemahnya bargaining power pihak-pihak Indonesia juga telah mempengaruhi penerapan hukum investasi asing yang sangat akomodatif terhadap investor-investor asing. Lihat T. Mulya Lubis, "PMA dan UUPMA: Harapan dan Kenyataan Sebuah Telaah Mengenai Kebijaksanaan Penanaman Modal," dalam Sumantoro ed., Hukum Ekonomi, Penerbit Universitas Indonesia, Jakarta, 1986, hal. 92.

31) M. Sornarajah, "The Climate of International Arbitration," J. Int'l Arb., Vol. 8 Tahun 1991, hal. 47-48. 
mereduksi dan mengeliminasi kendala-kendala yuridis, praktis dan judisial dalam pengakuan dan pelaksanaan putusan arbitrase asing. Tidak berlebihan apabila dikatakan bahwa reformasi sikap umum pemerintah Indonesia terhadap arbitrase perdagangan Intemasional sedang terjadi. Saat ini Indonesia berada dalam tahap transisi dari hostility ke hocpitability, dan dari non-enforcement policy ke enforcement policy. Kalau sampai saat ini pengakuan dan pelaksanaan putusan arbitrase asing di Indonesia masih menghadapi masalah, hal ini menunjukkan masih adanya sejumlah titik lemah. Untuk itu, adalah suatu keharusan untuk meng-"upgrade" kelemahankelemahan tersebut. Dalam konteks ini penulis merekomendasikan hal-hal berikut.

Pertama, untuk menutup kelemahan yuridis, kehadiran suatu Undang-undang tersendiri yang komprehensif mengenai arbitrase domestik dan internasional merupakan kebutuhan mendesak. Undangundang ini hendaknya meliputi tidak hanya pengaturan yang bersifat prosedural, tetapi juga hal-hal yang bersifat substantif. Ketentuan mengenai public policy dan upaya hukum banding dan kasasi hendaknya diberi perhatian yang lebih, karena hal ini sangat potensial untuk menjadi kendala utama terhadap kelancaran lalu lintas putusan arbitrase asing. Hukum-hukum yang ada telah tertinggal jauh dibelakang, dan oleh karena itu mampu untuk mengantisipasi perkembangan arbitrase perdagangan internasional. Selain undang-undang, adalah kebutuhan yang sangat urgen pula untuk mengadakan perjanjian-perjanjian bilateral, karena tidak semua negara meratidikasi Konvensi New York. Perjanjian-perjanjian bilateral tersebut akan sangat berguna terutama untuk mengantisipasi perlawanan yang didasarkan pada prinsip resiprositas.
Kedua, dalam kerangka meng-"upgrade" sikap masyarakat bisnis, adalah kebutuhan segara untuk mereduksi faktor-faktor yang menstimulasi mereka tidak melaksanakan putusan arbitrase asing. Pola hubungan partneralistik antara pengusaha-pengusaha Indonesia dengan para birokrat, termsuk pengadilan, yang melahirkan "client businessmen", hendaknya secara perlahanlahan diputus dengan cara mereduksi kebijakan-kebijakan proteksi. Pengadilan juga hendaknya sensitif terhadap pihak-pihak yang mempraktekan dilatory tactic. Sebaiknya pengadilan mengenakan persyaratan yang lebih bèrat atau hukuman tambahan terhadap piahak-pihak yang mempraktekan taktik tersebut untuk mencegah dilakukannya hal serupa. Adalah sangat juga bagi pengusaha-pengusaha Indonesia untuk mereduksi atau mengeliminasi dependensi mereka terhadap pengusaha-pengusaha asing, sehingga pada waktu yang bersamaan bargaining power mereka perlahan-lahan meningkat. Dengan demikian mereka akan dapat menghindar dari klausula-klausula kontrak yang menjerat mereka dan merugikannya.

Akhimya dari analisis permasalahan, yangmenjasi fokus tulisan ini, tampaknya variabel sikap pengadilan merupakan elemen kunci dari sukses atau gagalnya pengakuan pelaksanaan putusan arbitrase asing. Hal ini tidak lain karena betapa pun kurang memadainya perangkat yuridis, dan betapa pun kuatnya inkonsistensi masyarakat bisnis akan todak berarti apa-apa, jika pengadilan telah secara konsisten, dengan full faith and credit; menerapkan enforcement policy sebagai mana pengadilan Amerika, Belanda, Swiss dan Perancis. Oleh karena itu, variabel ini perlu mendapat prioritas perhatian. 


\section{Daftar Pustaka}

Caffrey, B.A., International Jurisdiction and Recognition and Enfercement of Foreign Judgments in the LAWASIA Region: A Comparative Study of the Laws of Eleven Asian Countries Inter-se and with the E.E.C. Countries, CCH Australian Limited, New South Wales, 1985.

Gautama, Sudargo, Masalah-masalah Baru Hukum Perdata Internasional, Alumni, Bandung, 1984.

"Some Legal Aspect of Commercial Arbitration in Indonesia", Journal of International Arbitration, Vol. 7 Tahun 1990, hal. 102.

Aneka Masalah Hukum Perdata Internasional, Alumni, Bandung, 1985.

Harahap, M. Yahya, Arbitrase, Pustaka Kartini, Jakarta, 1991.

Hill, Hal, Investasi Asing dan Industrialisasi Indonesia, LP3ES, Jakarta, 1991.

Hornick, Robert N., "The Recognition and Enforcement of Foreign Judgments in Indonesia", Harvard International Law Joumal, Vol. 18 Tahun 1977, hal. 102.

, "Indonesian Arbitration in Theory and Practice", American Joumal of Comparative Law, Vol. 39, Tahun, 1991, hal. 575.

Kusnandar, Winata E., "Perkembangan dan HambatanPelaksanaan Putusan Atbitrase Asing di Indonesia", Newsletter, VoI. 7/11 Tahun 1991, hal. 1.

Lubis, T. Mulya, "PMA dan UUPMA: Harapan dan Kenyataan Sebuah Telaah Mengenai Kebijaksanaan Penanaman Modal", dalam Sumantoro ed., Hukum Ekonomi, Penerbit Universitas Indonesia, Jakarta, 1986.
Muhaimin, Yahya A., Bisnis dan Politik: Kebijaksanaan Ekonomi Indonesia 1950-1980, LP3ES, Jakarta, 1991.

Noles, C., "Enforcement of Forum Selection Agreement in Contracts Between Unequal Parties", Georgia Joumal of International \& Comparative Law, Vol. 11 Tahun 1991, hal. 693.

Sornarajah, M., "The Climate of Internatioanl Arbitration", Journal of International Arbitration, Vol. 8 Tahun 1991, hal. 47.

Tumbuan \& Associates, "Indonesia", dalam C. Platoo ed., Enforcement of Foreign Judgment Worldwide, Graham \& Trotman and International Bar Association, London, 1989.

Wibisono, Christianto, "Anatomi Konglomerat Indonesia", dalam K.K. Gie \& B.N. Marbun, Konglomerat Indonesia: Permaslahan dan Sepak Terjangnya, Pustaka Sinar Harapan, Jakarta, 1990.

\section{Biodata}

ם Nandang Sutrisno, S.H., LL.M., alumnus Fakultas Hukum UII tahun 1985. Sejak tahun 1987 ia diangkat sebagai staf pengajar di fakultasnya. Memperoleh gelar Master of Laws (LL.M) dari Institute of Comparative Law, McGill University, Canada dalam bidang hukum bisnis internasional, dengan thesis "Recognition and Enforcement of Foreign Arbitral Award in Develoved and Develoving Countries: A Comparison of the United State and Indonesia". 